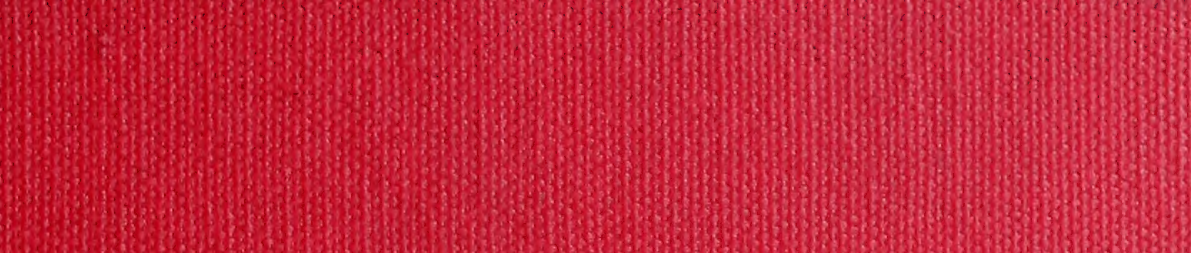
+.

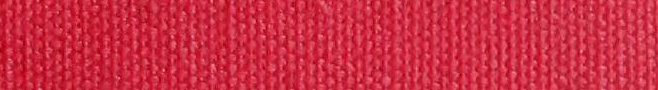

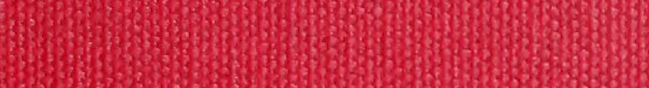
H.m.

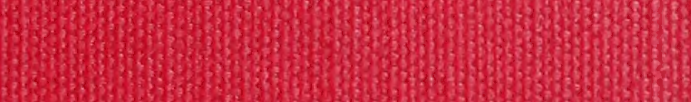

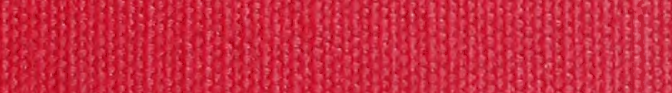

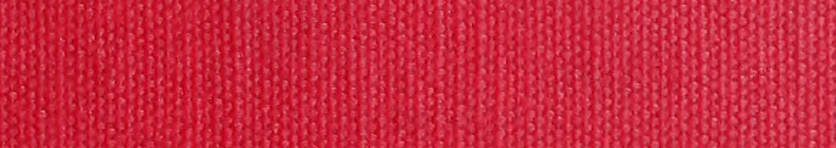
W.t. W.1.

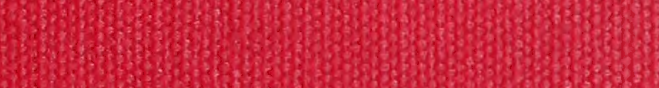

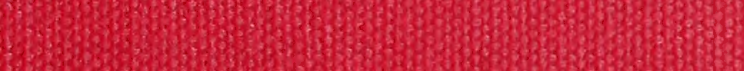

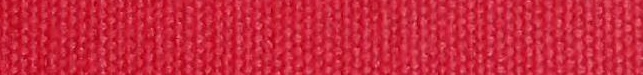

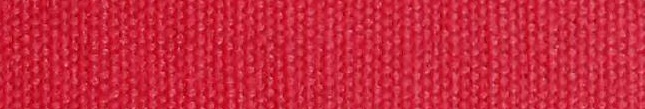

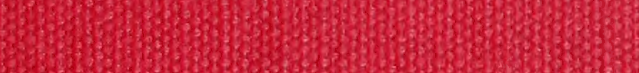

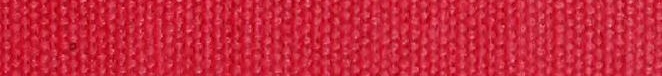

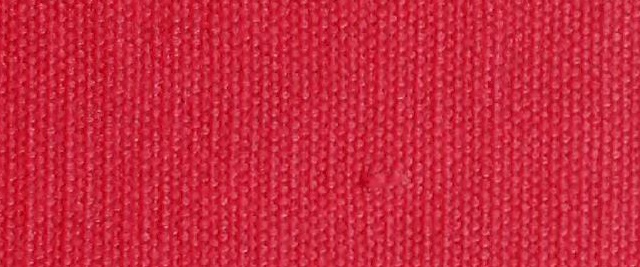

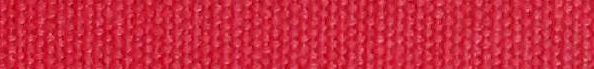

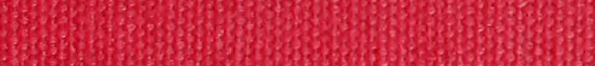

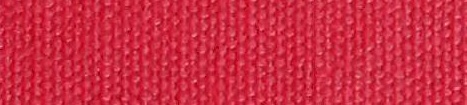
45.

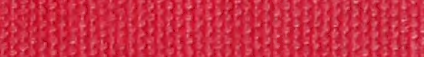

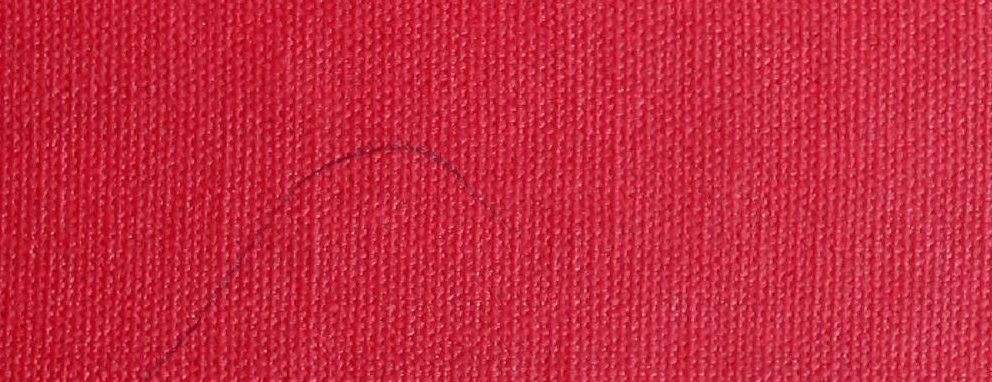
(2) (1) 



\section{Historic, archived document}

Do not assume content reflects current scientific knowledge, policies, or practices. 


\section{Market Quality and Rate of Respiration of HEAD LETTUCE Held in Low-Oxygen Atmospheres}

Marketing Research Report No. 777

Agricultural Research Service

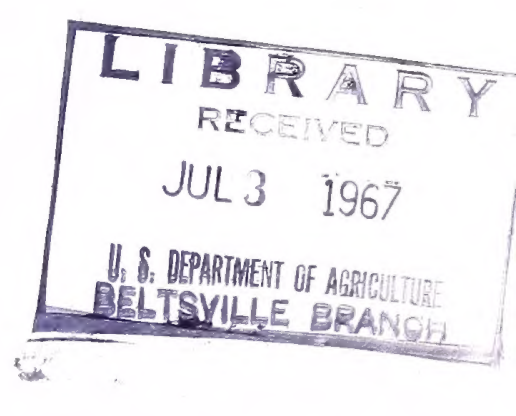

UNITED STATES DEPARTMENT OF AGRICULTURE 


\section{ACKNOWLEDGMENTS}

The cooperation of Bruce Church, Inc., Harden Farms of California, Inc., Bud Antle, Inc., and the Grower-Shipper Vegetable Association of Central California, all of Salinas, Calif., in furnishing the lettuce for these tests is gratefully acknowledged.

I appreciate the assistance of M. Uota with the carbon dioxide determinations and that of H. M. Couey with the statistical analyses.

\section{CONTENTS}

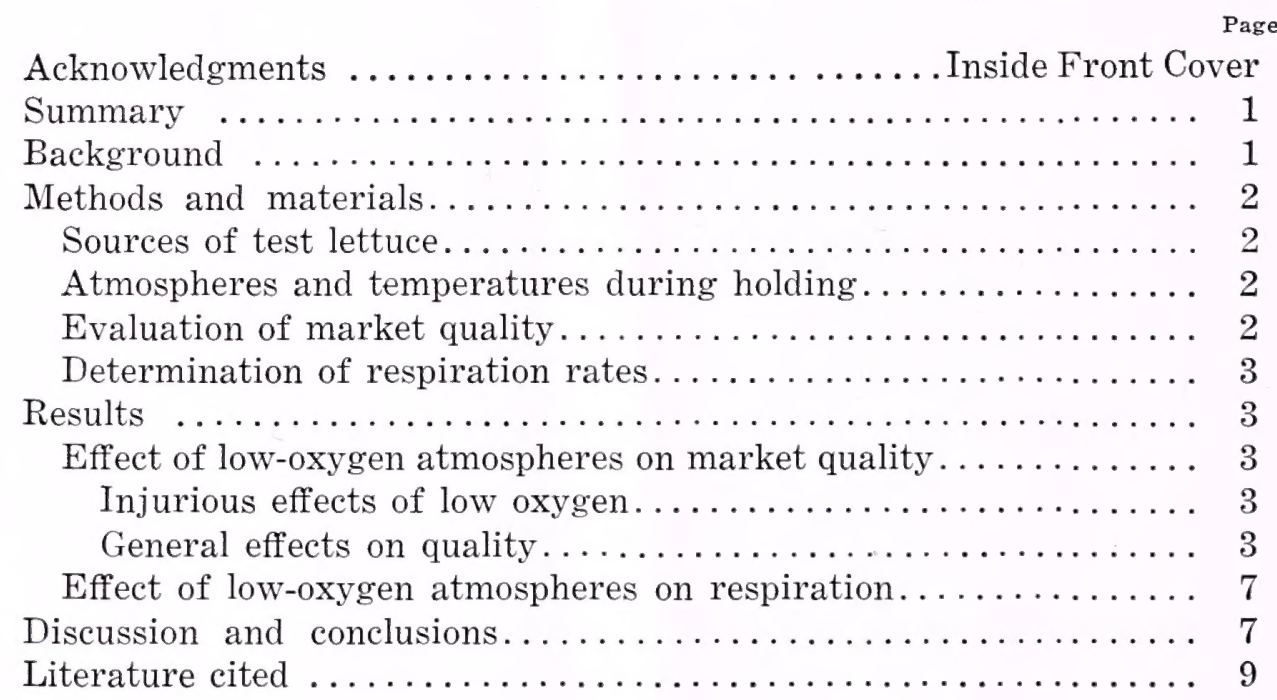




\title{
Market Quality and Rate of Respiration of Head Lettuce Held in Low-Oxygen Atmospheres
}

\author{
By W. J. Lipton, plant physiologist, ${ }^{1}$ Market Quality Research Division, \\ Agricultural Research Service, U.S. Department of Agriculture
}

\section{SUMMARY}

The market quality of head lettuce was evaluated after 7 days at $36^{\circ}, 41^{\circ}$, or $50^{\circ} \mathrm{F}$. in atmospheres containing $0,1 / 4,1 / 2,1,2,5$, or 8 percent $\mathrm{O}_{2}$ or in air and after an additional 3 or 4 days in air at $50^{\circ} \mathrm{F}$.

Concentrations of 0 and $1 / 4$ percent $\mathrm{O}_{2}$ injured the lettuce. Gray dead patches on the wrapper and cap leaves and dead young heart leaves were the principal symptoms of injury. The injuries became more severe as the temperature was increased.

Russet spotting was reduced substantially in all low-oxygen $\left(\mathrm{O}_{2}\right)$ atmospheres tested, regardless of temperature. The incidence of pink rib was not affected by low- $\mathrm{O}_{2}$ atmospheres. The severity, however, was reduced in $1 / 2$ percent $\mathrm{O}_{2}$ when all test temperatures are considered, but increased in 2 percent $\mathrm{O}_{2}$ at $50^{\circ} \mathrm{F}$.

Decay was reduced, but not significantly, in 1 percent $\mathrm{O}_{2}$. Low temperature was more effective in reducing decay than low $\mathrm{O}_{2}$.

Butt discoloration was generally less intense in $1 / 2$ and 1 percent $\mathrm{O}_{2}$ than in air, but not after 3 or 4 additional days in air.

The general appearance of nontrimmed lettuce was not affected significantly by holding it in $1 / 2$ to 8 percent $\mathrm{O}_{2}$ at $36^{\circ}$ or $41^{\circ} \mathrm{F}$.; although lettuce held at $50^{\circ}$ in $1,2,5$, or 8 percent $\mathrm{O}_{2}$ for 7 days plus 3 or 4 days in air appeared significantly greener and fresher than that held in air throughout. However, the quality of lettuce held in air at $36^{\circ}$ or $41^{\circ}$ was equal to and often superior to that held under low $\mathrm{O}_{2}$ at $50^{\circ}$. After the lettuce was trimmed, the only benefit from low $\mathrm{O}_{2}$ was a significant reduction in russet spotting.

The rate of respiration (carbon dioxide $\left[\mathrm{CO}_{2}\right]$ production) was reduced by about a third to a half in $1 / 2,1$, or 5 percent $\mathrm{O}_{2}$ compared with that in air, depending upon $\mathrm{O}_{2}$ concentration and temperature. At $41^{\circ}$, a 50-percent decrease in the rate of $\mathrm{CO}_{2}$ production would reduce vital heat production from 40,000 to 20,000 B.t.u. per day per 20-ton load of lettuce. This reduction of 20,000 B.t.u. is equivalent to the refrigeration capacity of about 140 pounds of ice or 115 pounds of liquid nitrogen $\left(\mathrm{N}_{2}\right)$.

When $\mathrm{N}_{2}$ is used as the refrigerant or as a supplement to mechanical refrigeration, the $\mathrm{O}_{2}$ concentration should be at least 1 percent, never less than $1 / 2$ percent. For maximum quality retention, low temperatures must accompany low- $\mathrm{O}_{2}$ atmospheres.

\section{BACKGROUND}

Liquid $\mathrm{N}_{2}$ has been used recently as a refrigerant or as a supplement to mechanical refrigeration in some shipments of western lettuce. The liquid $\mathrm{N}_{2}$ expands into a gas as it enters the load compartment, displaces the air, and thereby lowers the $\mathrm{O}_{2}$ content. Parsons and oth-

\footnotetext{
${ }^{1}$ Fresno, Calif.
}

ers $(6)^{2}$ found that very low $\mathrm{O}_{2}$ concentrations reduced russet spotting of lettuce, but Watada and others (12) reported that $\mathrm{O}_{2}$ concentrations from 1 to 15 percent had little effect on the rate of deterioration of lettuce. Further, Stewart

\footnotetext{
${ }^{2}$ Italic numbers in parentheses refer to Literature Cited, p. 9 .
} 
(10) noted undesirably high transit temperatures in shipments of lettuce refrigerated by $\mathrm{N}_{2}$. Harvey (3) cited evidence that atmospheres low in $\mathrm{O}_{2}$ injured some crops, although Parsons and others observed no injury on lettuce held in very low $\mathrm{O}_{2}$ concentrations for 10 days at $33^{\circ} \mathrm{F}$.

These divergent results needed to be clarified so that sound recommendations could be made to the lettuce industry on the safety or useful- ness of low- $\mathrm{O}_{2}$ atmospheres. Consequently, tests were conducted to evaluate the response of lettuce to such atmospheres at various temperatures.

Since a reduction in the heat of respiration is claimed as one advantage of shipping lettuce under low $\mathrm{O}_{2}$ (1), respiration was determined under various conditions.

\section{METHODS AND MATERIALS}

Sources of test lettuce: - Lettuce of the Great Lakes type was obtained in 1964 and 1965 from the Salinas Valley or near Mendota in the San Joaquin Valley of California. The lettuce was cut and packed by field crews, but, to reduce injury, only 18 heads were placed in each carton, instead of the customary 24. Lettuce from the Salinas Valley was vacuum cooled less than 1 hour after harvest and transported under refrigeration to the U.S. Department of Agriculture laboratory at Fresno, Calif.; that from the San Joaquin Valley was not vacuum cooled prior to storage because of the short transit time involved.

Atmospheres and temperatures during holding:- The lettuce was placed in stainless steel chambers and exposed to the appropriate atmospheres the same day it was harvested, or within 24 hours. The lots for each treatment contained an equal number of heads from each original carton for a total of 16 or 18 . Wet towels maintained a high relative humidity in the chambers. Adjacent heads were from different cartons to avoid introduction of potential nests of decay.

After closure, some chambers were flushed with $\mathrm{N}_{2}$ until the desired $\mathrm{O}_{2}$ concentration was nearly reached. The atmospheres were maintained by a continuous flow of the appropriate mixtures of $\mathrm{O}_{2}$ and $\mathrm{N}_{2}$ dispensed from highpressure cylinders. Atmospheres in chambers used as controls contained 21 percent $\mathrm{O}_{2}$ (air) and were maintained by a continuous flow of air.

The desired $\mathrm{O}_{2}$ concentration was generally reached within 4 to 6 hours after closing the chambers. The lettuce was held in $\mathrm{O}_{2}$ concentrations of zero, $1 / 4,1 / 2,1,2,5,8$, and 21 percent and at temperatures of $36^{\circ}, 41^{\circ}$, or $50^{\circ} \mathrm{F}$. Zero and $1 / 4$ percent $\mathrm{O}_{2}$ were not tested at $50^{\circ}$ because these atmospheres seriously injured the lettuce at $36^{\circ}$ and $41^{\circ}$. The $\mathrm{N}_{2}$ used to obtain zero percent $\mathrm{O}_{2}$ may have contained undetected traces of $\mathrm{O}_{2}$, which, however, were not sufficient to prevent low- $\mathrm{O}_{2}$ injury. The rate of flow was sufficient to keep $\mathrm{CO}_{2}$ levels below $1 / 2$ percent. The effluent gas had nearly the same $\mathrm{O}_{2}$ concentration as that entering the chambers, as monitored with a Burrell ${ }^{3}$ gas analyzer.

Evaluation of market quality : - The effect of each $\mathrm{O}_{2}$-temperature treatment on lettuce was evaluated in at least three tests. Half the lettuce was examined after 7 days in the atmospheres evaluated (simulated transit period), and the remainder after an additional 3 or 4 days in air at $50^{\circ} \mathrm{F}$. (simulated wholesale-retail period). Each head was rated for russet spotting, pink rib, and decay on a scale from 1 to 9 ( $1=$ defects absent, $3=$ trace, $5=$ slight, $7=$ moderate, $9=$ severe). Observations on butt discoloration and injury from low- $\mathrm{O}_{2}$ concentration were made when appropriate. The general appearance of the heads with and without wrapper leaves was rated on a scale from 9 to 1 $(9=$ field fresh, no defects $; 7=$ good, minor defects; $5=$ fair, objectionable defects that can be removed before sale; $3=$ poor, generally unsalable; $1=$ inedible).

The large number of treatments precluded their incorporation in any one test. Thirteen

\footnotetext{
${ }^{3}$ Trade names and the names of commercial companies are used in this publication solely to provide specific information. Mention of a trade name or manufacturer does not constitute a guarantee or warranty of the product by the U.S. Department of Agriculture or an endorsement by the Department over other products not mentioned.
} 
tests were conducted during the two seasons. Each test included eight treatments, three low$\mathrm{O}_{2}$ concentrations and one air control at each of two temperatures. A given treatment was tested at intervals during a growing season to avoid seasonal bias. The combined data from all tests were evaluated on an equal basis by applying the analysis of variance (Duncan's Multiple Range Test) for unequal sample size to the data which were calculated as a percentage of averages obtained for the lots held in air for a given temperature. (For example, average severity rating for pink rib at $50^{\circ} \mathrm{F}$. in air, 4.0 ; in 2 percent $\mathrm{O}_{2}, 6.0$; relative value for air, 100 ; for 2 percent $\mathrm{O}_{2}, 150$.) The results of tests that differed substantially from the trend were also analyzed separately to gain information that would be lost in the averages of all tests.

Determination of respiration rates: $-\mathrm{CO}_{2}$ production was measured on lettuce grown in the Imperial Valley of California (January to March 1966) and obtained from a local wholesaler 24 to 36 hours after harvest. The lettuce was held in glass jars at $41^{\circ}$ or $50^{\circ} \mathrm{F}$. in $1 / 2,1$, 5 , or 21 percent $\mathrm{O}_{2}$ (air). Six heads were used for the $41^{\circ}$ treatments, five heads for the $50^{\circ}$ treatments. Each treatment was tested twice. The graphs in figure 1 represent the average values of the replicates at each temperature.

$\mathrm{CO}_{2}$ was determined with a positive nondispersive-type infrared analyzer (Liston-Becker, model 15A) connected to a Varian strip chart recorder set at zero to 0.250 percent $\mathrm{CO}_{2}$ full scale. A given gas sample passed through the analyzer for about 4 minutes at about $11 / 2$-hour intervals, as regulated by an automatic manifold. $\mathrm{CO}_{2}$-free air and $\mathrm{O}_{2}-\mathrm{N}_{2}$ mixtures were used in the respiration studies.

\section{RESULTS}

\section{Effect of Low-Oxygen Atmospheres on Market Quality}

Injurious effects of low oxygen:-Extensive gray, dead patches developed on the wrapper leaves of lettuce held 7 days in zero percent $\mathrm{O}_{2}$ at $36^{\circ}$ or $41^{\circ} \mathrm{F}$. These injuries were present to a lesser degree on wrapper leaves held in $1 / 4$ percent $\mathrm{O}_{2}$ (pl. 1 ), but were more widespread and severe after the additional 3 or 4 days in air at $50^{\circ}$ than at the first examination. Cap leaves of heads held previously in zero percent $\mathrm{O}_{2}$ also developed gray, dead patches. Injury to heart leaves from low $-\mathrm{O}_{2}$ concentrations appeared as reddish-brown spots (pl. 2) on the midribs of leaves near the center of the head. Zero percent $\mathrm{O}_{2}$ caused injury to wrapper, cap, and heart leaves, but $1 / 4$ percent $\mathrm{O}_{2}$ caused the death of only the heart leaves.

Both the incidence and severity of the external and internal injuries increased as the temperatures increased. In one test at $50^{\circ} \mathrm{F}$., the heart leaves died even in 0.3 to 0.4 percent $\mathrm{O}_{2}$. The injuries developed further after removal of the lettuce to air at $50^{\circ}$, and decay often affected the injured wrapper leaves during this simulated wholesale-retail period.

Off-flavors-sweet, flat, not typical of lettuce -were detected in heads held in zero and $1 / 4$. percent $\mathrm{O}_{2}$ and were sometimes more prominent in samples held at the higher concentration. These off-flavors generally disappeared after the lettuce was held 3 or 4 days in air at $50^{\circ}$.

General effects on quality :- Substantial inhibition of russet spotting (4) was the principal benefit of low $-\mathrm{O}_{2}$ atmospheres in tests where this disorder occurred. The incidence was reduced about equally in zero to 8 percent $\mathrm{O}_{2}$ and at all three temperatures (table 1 ).

Not only the incidence, but also the severity of russet spotting was reduced in the low $-\mathrm{O}_{2}$ atmospheres. The severity, as a percentage of that in air, ranged from 29 to 66 percent, both values being significantly lower (99-percent probability level) than that in air. Differences among individual treatments were not tested statistically because the sporadic occurrence of russet spotting resulted in too few data for reliable analysis.

The incidence of pink rib, which was evident in all tests and in all treatments, wo not affected significantly by low- $\mathrm{O}_{2}$ atmos neres. The incidence, as a percentage of thr in air, ranged from 74 percent in $1 / 2$ percent $\mathrm{O}_{2}$ to 103 percent in 8 percent $\mathrm{O}_{2}$. 


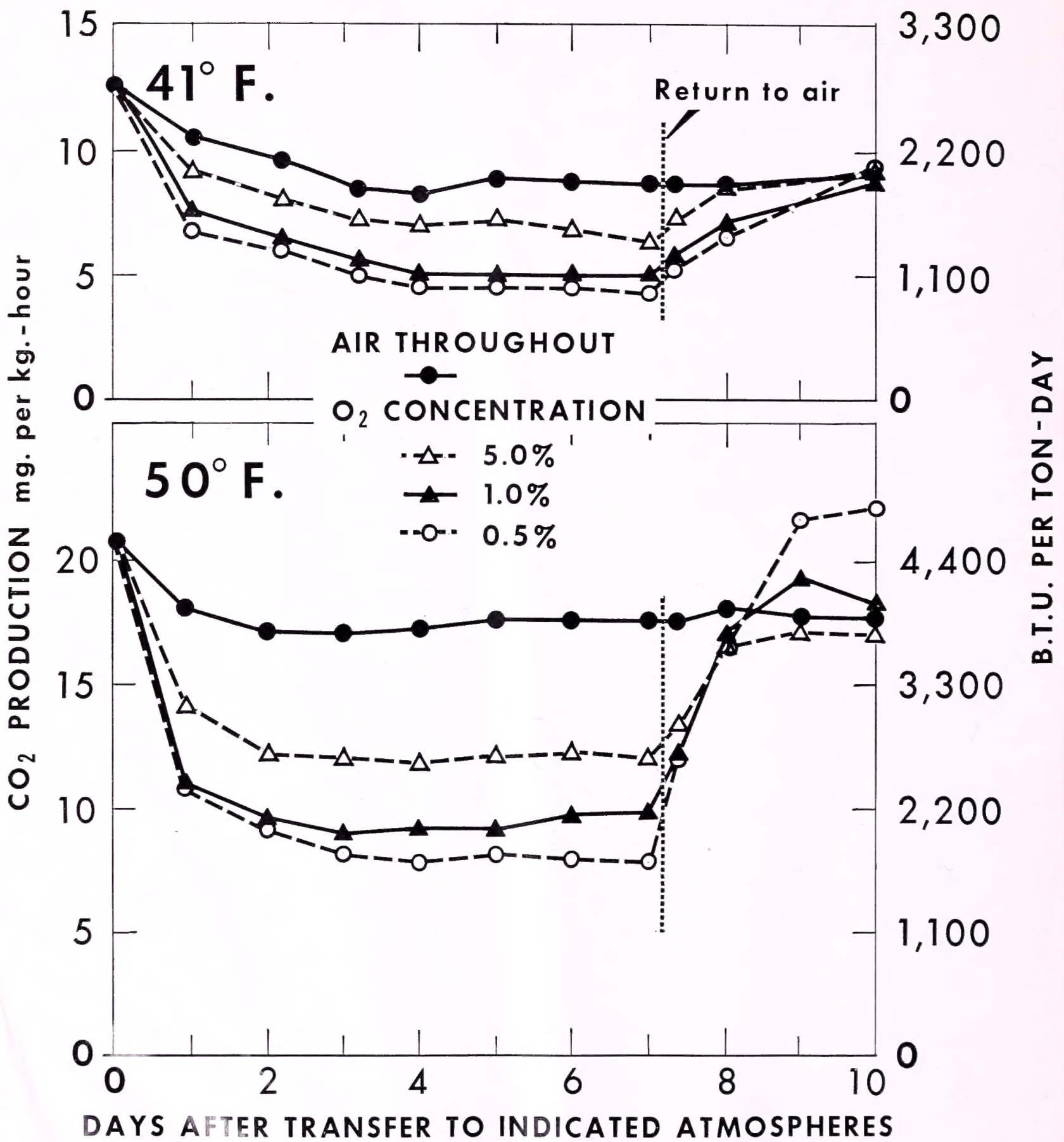

FiguRE 1. - $\mathrm{CO}_{2}$ production by lettuce held in various $\mathrm{O}_{2}$ concentrations at $41^{\circ}$ or $50^{\circ} \mathrm{F}$. and after the return to air. 
TABLE 1.-Incidence of russet spotting, severity of pink rib, and overall quality of lettuce held in various low-oxygen atmospheres

[All values expressed are relative to their percentages in air (21 percent $\mathrm{O}_{2}$ ). Figures on a given line without a common letter differ at the 95-percent probability level. A verages are for all samples at any one $\mathrm{O}_{2}$ concentration; they are not equal to the averages of each column because of the unequal numbers of samples in each treatment. At least 48 heads were evaluated for each treatment]

\begin{tabular}{|c|c|c|c|c|c|c|}
\hline \multirow{2}{*}{$\begin{array}{l}\text { Storage temperature } \\
\left({ }^{\circ} \mathrm{F} .\right)\end{array}$} & \multicolumn{6}{|c|}{$\begin{array}{c}\text { Values for lettuce held } 7 \text { days in the following percentages of oxygen }{ }^{1} \\
\text { plus } 3 \text { or } 4 \text { days in air at } 50^{\circ} \mathrm{F} \text {. }\end{array}$} \\
\hline & $1 / 2$ & 1 & 2 & 5 & 8 & 21 \\
\hline 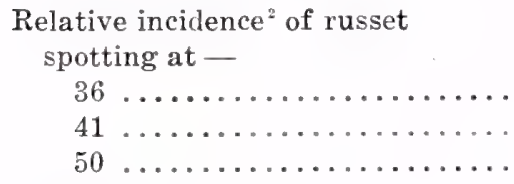 & $\begin{array}{l}\text { Pct. } \\
\begin{array}{l}3 \mathrm{a} \\
0 \mathrm{a} \\
\left({ }^{3}\right)\end{array}\end{array}$ & $\begin{array}{rl}\text { Pct. } & \\
21 & \mathrm{a} \\
17 & \mathrm{a} \\
0 & \mathrm{a}\end{array}$ & $\begin{array}{rl}\text { Pct. } & \\
7 & \mathrm{a} \\
19 & \mathrm{a} \\
0 & \mathrm{a}\end{array}$ & $\begin{array}{l}\text { Pct. } \\
\begin{array}{rl}13 & \mathrm{a} \\
0 & \mathrm{a} \\
0 & \mathrm{a}\end{array}\end{array}$ & $\begin{array}{l}\text { Pct. } \\
19 \text { a } \\
13 \text { a } \\
0 \text { a }\end{array}$ & $\begin{array}{l}\text { Pct. } \\
100 \mathrm{~b} \\
100 \mathrm{~b} \\
100 \mathrm{~b}\end{array}$ \\
\hline Average $\ldots \ldots \ldots \ldots \ldots \ldots$ & 2 a & $17 \mathrm{a}$ & $9 \mathrm{a}$ & 6 a & 12 a & $100 \mathrm{~b}$ \\
\hline 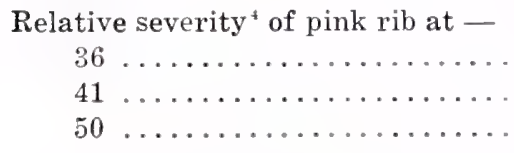 & $\begin{array}{l}84 \mathrm{a} \\
81 \mathrm{a} \\
80 \mathrm{a}\end{array}$ & $\begin{array}{c}83 \mathrm{a} \\
85 \mathrm{a} \\
127 \mathrm{~cd}\end{array}$ & $\begin{array}{r}89 \mathrm{a} \\
82 \mathrm{a} \\
133 \mathrm{~d}\end{array}$ & $\begin{array}{c}99 \text { a } \\
98 \text { a } \\
117 \text { bcd }\end{array}$ & $\begin{array}{rl}98 & \mathrm{a} \\
98 & \mathrm{a} \\
121 & \mathrm{~cd}\end{array}$ & $\begin{array}{l}100 \mathrm{a} \\
100 \mathrm{a} \\
100 \mathrm{abc}\end{array}$ \\
\hline Average $\ldots \ldots \ldots \ldots \ldots \ldots$ & $82 \mathrm{a}$ & $96 \mathrm{ab}$ & $100 \mathrm{~b}$ & $104 \mathrm{~b}$ & $105 \mathrm{~b}$ & $100 \mathrm{~b}$ \\
\hline 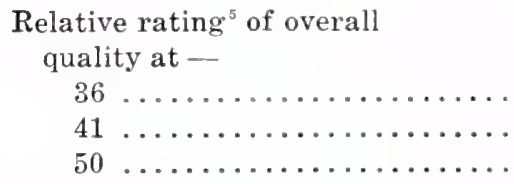 & $\begin{array}{l}103 \mathrm{a} \\
103 \mathrm{a} \\
120 \mathrm{~b}\end{array}$ & $\begin{array}{l}104 \mathrm{a} \\
105 \mathrm{a} \\
138 \mathrm{~b}\end{array}$ & $\begin{array}{l}103 \mathrm{a} \\
104 \mathrm{a} \\
129 \mathrm{~b}\end{array}$ & $\begin{array}{l}107 \mathrm{a} \\
106 \mathrm{a} \\
123 \mathrm{~b}\end{array}$ & $\begin{array}{l}106 \mathrm{a} \\
101 \mathrm{a} \\
127 \mathrm{~b}\end{array}$ & $\begin{array}{l}100 \mathrm{a} \\
100 \mathrm{a} \\
100 \mathrm{a}\end{array}$ \\
\hline Average $\ldots \ldots \ldots \ldots \ldots \ldots$ & $107 \mathrm{a}$ & $114 \mathrm{a}$ & $111 \mathrm{a}$ & $112 \mathrm{a}$ & $111 \mathrm{a}$ & $100 \mathrm{a}$ \\
\hline
\end{tabular}

${ }^{3}$ Data for zero percent and $1 / 4$ percent $O_{2}$ not included because these atmospheres seriously injured the lettuce.

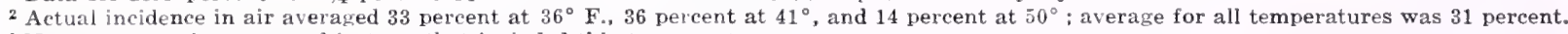

${ }^{3}$ No russet spotting occurred in tests that included this treatment.

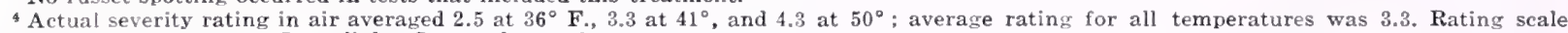
used : $1=$ none, $3=$ trace, $5=$ slight, $7=$ moderate, $9=$ severe.

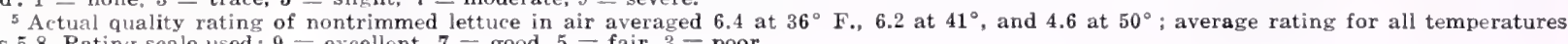
was 5.8. Rating scale used : $9=$ excellent, $7=$ good, $5=$ fair, $3=$ poor.

The severity of pink rib was reduced significantly in $1 / 2$ percent $\mathrm{O}_{2}$ (table 1 ). In contrast, the severity was intensified by $1,2,5$, or 8 percent $\mathrm{O}_{2}$ at $50^{\circ} \mathrm{F}$. in almost every test; the increase was greatest in 2 percent $\mathrm{O}_{2}$ (table 1 ). Pink rib was sufficiently severe to detract from the market value of much of the lettuce (see table 1 , footnote 4 ). At $36^{\circ}$ or $41^{\circ}$, none of the atmospheres affected the severity of pink rib significantly.

The effect of low- $\mathrm{O}_{2}$ atmospheres on the incidence of decay was inconsistent. Although lettuce held in 1 percent $\mathrm{O}_{2}$ had slightly less decay after the simulated transit period plus 3 or 4 days in air (the incidence was 66 percent of that in air) than that from the other atmospheres, none of the differences were statistically significant. Temperature exerted a greater in- fluence on decay than $\mathrm{O}_{2}$ concentration : the incidence of decay increased as temperature increased from $36^{\circ}$ to $50^{\circ} \mathrm{F}$. Heads held under low $\mathrm{O}_{2}$ at $50^{\circ}$ had consistently more decay than those held in air at $36^{\circ}$ or $41^{\circ}$. No trend existed in respect to severity of decay. The decay that did occur was usually confined to the wrapper leaves and was not serious.

Butt discoloration varied widely within a given treatment but was generally less severe in $1 / 2$ percent or 1 percent $\mathrm{O}_{2}$ than in air ( $\mathrm{pl} .3$ ). Holding the lettuce 3 or 4 days in air at $50^{\circ} \mathrm{F}$. completely negated any differences that existed immediately after the lettuce was removed from $1 / 2$ or 1 percent $\mathrm{O}_{2}$. The cut surface remained white only at zero or $1 / 4$ percent $\mathrm{O}_{2}$, concentrations that injured the lettuce severely. 
The appearance of nontrimmed lettuce was affected very little by storage in $1 / 2$ to 8 percent $\mathrm{O}_{2}$ at $36^{\circ}$ or $41^{\circ} \mathrm{F}$., temperatures near and slightly above desirable levels. At $41^{\circ}$, lettuce held in low $-\mathrm{O}_{2}$ ( 1 percent) concentrations was significantly superior to that held in air in only one test. However, atmospheres in the range of 1 to 8 percent $\mathrm{O}_{2}$ improved the appearance of lettuce held at $50^{\circ} \mathrm{F}$. (table 1$)$. Lettuce in these treatments remained greener and had a fresher appearance than that held in air. This difference was not evident immediately after removal from low $\mathrm{O}_{2}$, but only after the simulated wholesale-retail period in air at $50^{\circ}$. The appearance of lettuce held in air at low temperatures was commonly superior to that of lettuce held in low $-\mathrm{O}_{2}$ concentrations at the next higher temperature. Therefore, low $\mathrm{O}_{2}$ cannot be considered an improvement over low temperature in maintaining the market quality of lettuce when russet spotting is not a problem.

Trimming off the wrapper leaves removed all evidence of the favorable effect of low $\mathrm{O}_{2}$ on general appearance. The amount of $\mathrm{O}_{2}$ had little effect on trimmed lettuce either "on arrival" or after the simulated wholesale-retail period in air; only those benefits related to reduction in russet spotting remained. The effect of low $\mathrm{O}_{2}$ on pink rib was variable, as previously noted.

\section{Effect of Low-Oxygen Atmospheres on Respiration}

Atmospheres with $1 / 2,1$, or 5 percent $\mathrm{O}_{2}$ reduced the rate of $\mathrm{CO}_{2}$ production of lettuce held at $41^{\circ}$ or $50^{\circ} \mathrm{F}$. (fig. 1), and the percentage reductions were similar at both temperatures. In $1 / 2$ and 1 percent $\mathrm{O}_{2}$ the rate of $\mathrm{CO}_{2}$ production was reduced by about half of that in air and in 5 percent $\mathrm{O}_{2}$ by about a third. These results parallel those for spinach ( $\%$ ) and for a variety of other plants $(2,11)$. As would be expected, the rates were higher at $50^{\circ}$ than at $41^{\circ}$; in fact, at $50^{\circ}, \mathrm{CO}_{2}$ production in $1 / 2$ percent or 1 percent was about the same as at $41^{\circ}$ in air.

The rate of $\mathrm{CO}_{2}$ production adjusted to the lowered $\mathrm{O}_{2}$ concentrations about 3 days after the change from air at both temperatures. In contrast, the return to the normal rate of $\mathrm{CO}_{2}$ production after the lettuce was again placed in air was more rapid at $50^{\circ} \mathrm{F}$. than at $41^{\circ}$. Further, at $50^{\circ}$, the rates for the lettuce held previously in $1 / 2$ or 1 percent $\mathrm{O}_{2}$ exceeded the rates of lettuce held in air throughout by 25 and 11 percent, respectively, before they leveled off-2 days after the return to air. Bourne and Ranson (2) observed a similar increase in $\mathrm{CO}_{2}$ production after removal of rhododendron leaves from an $\mathrm{N}_{2}$ atmosphere into air. This increase in $\mathrm{CO}_{2}$ production above that existing in the air control, was almost absent at $41^{\circ}$.

\section{DISCUSSION AND CONCLUSIONS}

The foregoing results indicate that some definite, but limited, benefits may be derived from the use of certain low- $\mathrm{O}_{2}$ atmospheres under conditions simulating the transcontinental shipment of head lettuce. The substantial reduction in russet spotting, even at $\mathrm{O}_{2}$ concentrations as high as 8 percent, is clearly the major benefit. This response, previously observed by Parsons and others $(6)$ in lettuce held at very low $\mathrm{O}_{2}$ concentrations, is surprising at the higher $\mathrm{O}_{2}$ concentrations because the rate of $\mathrm{CO}_{2}$ production, a measure of metabolic activity, was substantially higher in 5 percent $\mathrm{O}_{2}$ than in $1 / 2$ or 1 percent $\mathrm{O}_{2}$ (fig. 1 ). It appears, therefore, that russet spotting is inhibited at $\mathrm{O}_{2}$ concentrations substantially higher than those that reduce $\mathrm{CO}_{2}$ production appreciably. In contrast, the browning reaction associated with butt discoloration was prevented only in near anaerobic conditions, both in these tests and in those of Parsons and others. Pink rib, also the result of an oxidative discoloration, was actually enhanced in 1 or 2 percent $\mathrm{O}_{2}$, but reduced in $1 / 2$ percent $\mathrm{O}_{2}$ at $50^{\circ} \mathrm{F}$. These apparently paradoxical results cannot be clarified on the basis of the present tests, but they suggest that the circumstances that lead to russet spotting differ substantially from those that cause pink rib.

The small young heart leaves were most sensitive to low $-\mathrm{O}_{2}$ injury and, therefore, would be a good indicator of the adequacy of the $\mathrm{O}_{2}$ sup- 
ply for lettuce during transit. The grayishbrown discoloration, especially at the leaf margins, was quite distinct from the reddish-brown discoloration caused by excess $\mathrm{CO}_{2}$ (12). However, the reddish spots on the midrib of the central head leaves found in zero percent $\mathrm{O}_{2}$ did resemble those described for $\mathrm{CO}_{2}$ injury. Some of the external and internal injuries observed in lettuce held in zero percent and 1/2 percent $\mathrm{O}_{2}$ resembled those attributed to "suboxidation" by Nelson (5). Parsons and others (6) did not observe these injuries, possibly because metabolic activity is lower at $33^{\circ}$ than at $36^{\circ} \mathrm{F}$. or above, or because not all entrapped $\mathrm{O}_{2}$ was removed by flushing the chambers with $\mathrm{N}_{2}$ for 10 to 15 minutes twice daily.

The lack of substantial effect of low $\mathrm{O}_{2}$ on the general appearance of lettuce, especially after trimming, agrees closely with the results of Watada and others (12), who found that $\mathrm{O}_{2}$ concentrations from 1 to 15 percent neither improved nor harmed lettuce held at $36^{\circ}$ or $41^{\circ} \mathrm{F}$. Watada and co-workers did not include $50^{\circ}$ in their tests; this temperature, while undesirably high, does occur in lettuce shipped under liquid $\mathrm{N}_{2}$ refrigeration (10). The retardation in quality loss resulting from 1 to 8 percent $\mathrm{O}_{2}$ at $50^{\circ}$, but not at $41^{\circ}$ or $36^{\circ}$, is related to the rate of deterioration at these temperatures. At $41^{\circ}$ or below, sound lettuce remains in fairly good condition for nearly 2 weeks (8), so that color retention by wrapper leaves is not affected by low $\mathrm{O}_{2}$ concentrations during shorter intervals. In contrast, at $50^{\circ}$ the senescence retarding effect of low $\mathrm{O}_{2}$ becomes noticeable because of the substantially higher rate of deterioration at this temperature. However, during long periods of storage, such as may occur in the supply of navy ships, the benefits of low $\mathrm{O}_{2}$ also may be apparent near $40^{\circ} \mathrm{F}$. Similarly, any beneficial effects of low $\mathrm{O}_{2}$ on lettuce quality would be progressively less noticeable as the transit period is shortened.
The low incidence and severity of decay found in these laboratory tests, especially at $50^{\circ} \mathrm{F}$., may be explained by the careful handling the lettuce received. In commercially packed and shipped lettuce, decay was substantial in $\mathrm{O}_{2}$ concentrations of 2 percent or lower when transit temperatures were about $50^{\circ} \mathrm{F}$. (10).

The data on $\mathrm{CO}_{2}$ production allow determination of possible savings in the cost of refrigeration if lettuce is shipped in low- $\mathrm{O}_{2}$ atmospheres. With a rate of heat production of about 2,000 B.t.u. per ton-day in air at $41^{\circ} \mathrm{F}$., a 50-percent reduction lowers the heat of respiration from 40,000 to 20,000 B.t.u. per day in a 20 -ton load of lettuce. This reduction of 20,000 B.t.u. is equivalent to the refrigeration capacity of about 140 pounds of ice or 115 pounds of liquid $\mathrm{N}_{2}$. This relatively small saving lasts only as long as the $\mathrm{O}_{2}$ level remains near 1 percent; if it rises, as has occurred when the supply of liquid $\mathrm{N}_{2}$ was exhausted before arrival (10), normal rates of $\mathrm{CO}_{2}$ production are approached rapidly or even exceeded. The savings would be slightly greater with lettuce respiring at the somewhat higher rates reported for lettuce from the Salinas Valley (8) or the Rio Grande Valley (9).

It follows from the above discussion that low$\mathrm{O}_{2}$ atmospheres do not benefit lettuce substantially except in respect to russet spotting, which was reduced significantly and about equally in $1 / 2$ to 8 percent $\mathrm{O}_{2}$. Further, for maximum quality retention, low temperatures (not above $41^{\circ}$ ) must accompany low- $\mathrm{O}_{2}$ concentrations. When $\mathrm{N}_{2}$ is used as a refrigerant or as a supplement to mechanical refrigeration, the $\mathrm{O}_{2}$ level should remain near 1 percent or higher, never below $1 / 2$ percent because of the danger of serious injury at lower concentrations.

These deterioration and respiration studies clearly show that low- $\mathrm{O}_{2}$ atmospheres neither stop deterioration of lettuce nor "immediately put [lettuce] to sleep" as has been claimed (1). 


\section{LITERATURE CITED}

(1) AnONYMOUS.

1966. USE OF OXYGEN CONTROL TO STOP Deterioration. The Packer $73(4): 16$, illus.

(2) Bourne, D. T., and Ranson, S. L.

1965. RESPIRATORY METABOLISM IN DETACHED RHODODENDRON LEAVES. Plant Physiol. 40: 1178-1190, illus.

(3) HARVEY, J. M.

1965. NITROGEN-ITS STRATEGIC ROLE IN PRODUCE FRESHNESS. Prod. Market. 8(7) : 17-18.

(4) LiptoN, W. J.

1961. ANATOMICAL OBSERVATIONS ON RUSSET SPOTTING AND PINK RIB of LETTUCE. Amer. Soc. Hort. Sci. Proc. 78: 367-374, illus.

(5) NELSON, R.

1926. STORAGE AND TRANSPORTATIONAL DISEASES OF VEGETABLES DUE to suboxidation. Mich. Agr. Expt. Sta. Tech. Bul. 81, 38 pp., illus.

(6) Parsons, C. S., Gates, J. E., and SpaldING, D. H.

1964. QUALITY OF SOME FRUITS AND VEGETABLES AFTER HOLDING IN NitRogen ATMOSPHERES. Amer. Soc. Hort. Sci. Proc. 84: 549556.

(7) Platenius, $\mathrm{H}$.

1943. EFFECT OF OXYGEN CONCENTRATION ON THE RESPIRATION OF SOME VEGETABLEs. Plant Physiol. 18: 671-684, illus.
(8) Pratt, H. K., Morris, L. L., and Tucker, C. L.

1954. TEMPERATURE AND LETTUCE DETERIORATION. Conf. Transport. Perishables Proc., Univ. Calif., Davis: 77-83, illus.

(9) Scholz, E. W., Johnson, H. B., and BUFORD, W. R.

1963. HEAT EVOLUTION RATES OF SOME TEXAS-GROWN FRUITS AND VEGETABLES. Rio Grande Valley Hort. Soc. Jour. 17: 170-175.

(10) Stewart, J. K., and others.

1966. NITROGEN - ITS EFFECT ON TRANSIT TEMPERATURES AND MARKET QUALITY OF WESTERN LETTUCE SHIPPED IN PIGGYBACK Trailers. U.S. Dept. Agr. Market. Res. Rpt. 759, 14 pp., illus.

(11) Stiles, $W$

1960. THE COMPOSITION OF THE ATMOSPHERE (OXYGEN CONTENT OF AIR, WATER, SOIL, INTERCELLULAR SPACES, DIFFUSION, CARBON DIOXIDE, AND OXYGEN TENSION). Encyclop. Plant Physiol. [W. Ruhland, ed.] 12 (2) : 114 118 , illus.

(12) Watada, A. E., Morris, L. L., and RapPAPORT, L.

1964. MODIFIED ATMOSPHERE EFFECTS ON LETTUCE. Fruit and Vegetable Perishables Handling Conf. Proc., Univ. Calif., Davis: 82 85 , illus. 

